\title{
Cognitive Deficiency in Cannabis Consumers
}

\author{
Wurgan Rahadian*1, Abraham Sabda Respati ${ }^{2}$, Supra Wimbarti ${ }^{3}$, Sri Kusrohmaniah ${ }^{4}$ \\ 1,2,3,4 Faculty of Psychology, Universitas Gadjah Mada
}

Submitted 7 September 2020 Accepted 16 October 2020 Published 2 December 2021

\begin{abstract}
While being the most abused psychoactive substance (PS), cannabis is also the least researched PS (especially) in Indonesia. Since 24\% of total PS abusers within the last year is students, we could only form an a priori on what cannabis consumption might lead to for the cognitive functions of the students. A study to explore what would happen to cognitive functions due to cannabis consumption is important. This article aims (1) to explore the effects induced by cannabis in human cognitive functions and (2) to explore which part of the brain correlates with cognitive functions affected by cannabis consumption. We conducted a literature review to answer the questions. This article shows that there is no clear conclusion whether cannabis induced positive or negative effects to human cognitive functions. It is due to various sampling technique used by the studies cited within this article. Future research on the cognitive functions of cannabis consumer should really taking population in which they tried to sample into consideration. Moreover, it is delicate to determine causality relationship between consuming cannabis and poor cognitive functions.
\end{abstract}

Keywords: cannabis; cognitive functions; neurocognitive

\section{Introduction}

Cannabis is a genus of flowering plant as well as PS. In 2017, an estimated 1,7 million people in Indonesia aged 10-59 years consumed this flowering plant in the previous year, making it the most consumed PS in Indonesia (Pusat Penelitian Data dan Informasi Badan Narkotika Nasional Republik Indonesia [BNN] \& Pusat Penelitian Kesehatan Universitas Indonesia [UI] (BNN \& UI, 2017)). However, while listed as the most consumed, cannabis is the least researched PS in Indonesia ${ }^{1}$ (Saputro, 2018). This anomaly contradicts the fact that in Indonesia, cannabis could only be researched and/or as diagnostic reagent and not to be consumed (Undang-undang Nomor 35 Tahun 2009 tentang Narkotika, 2009).

Twenty-four percent of the previous year prevalence (3.3 million) were students (BNN \& UI, 2017), which were approximately adolescence, a phase when the brain is experiencing fundamental reorganization (Konrad et al., 2013). According to Konrad et al. (2013), this fundamental reorganization

\footnotetext{
*Address for correspondence: wurgan.rahadian@mail.ugm.ac.id

${ }^{1}$ BNN through a letter numbered B/2474/X/201/BNN to Lingkar Ganja Nusantara (LGN) on 6 October 2011 confirmed that there is no specific study formally conducted by Indonesian government towards cannabis (Nusantara, 2014). However, Sujono and Daniel (2013) state that BNN with Indonesia National Institute on Drug Abuse and Monash University ever conducted a study towards cannabis. Moreover, not only in Indonesia, compared to other PS, cannabis is the least studied PS globally (Balhara \& Jain, 2014).
} 
is associated with the extent of emotional and cognitive maturation. Cognitive maturation is shaped by the development of executive function, which governs on how we think and behave, resulting in flexible adaptability to a new and more complex tasks (Blakemore \& Choudhury, 2006) In addition to executive function, cognitive maturation is also shaped by the development of social cognitive, e.g., ability to recognize faces and to empathize (Blakemore, 2008).

It is important to study the effects cannabis might induce to cognitive functions, since a longitudinal study shows that cannabis consumption during adolescence correlates with schizophrenia onset in adulthood (Arseneault et al., 2002). In line with Arseneault et al. (2002), another longitudinal study shows that there is a correlation between cannabis consumption during young adulthood and symptoms associated with schizophrenia (Andréasson et al., 1987). Nevertheless, both longitudinal studies did not consider predisposition factor before the onset of cannabis consumption.

Although there is a correlation between cannabis consumption and schizophrenia (Andréasson et al., 1987; Arseneault et al., 2002)), it does not imply that cannabis consumption might induce schizophrenia. Individuals with predisposition to schizophrenia tend to consume cannabis (Pinel, 2009). However, a background check to psychosis incidence during childhood should be made to prevent future consumption to cannabis (Arseneault et al., 2002). Furthermore, in non-predisposition group - even though the study did not divide between predisposition and non-predisposition groups; general population-cannabis consumption accounts for only a minority of all schizophrenia cases (Andréasson et al., 1987).

Recent studies show antipsychotic properties of one of the cannabinoids ${ }^{2}$ Cannabidiol (CBD) as a constituent of the cannabinoids and mostly binds to cannabinoid receptor type $2\left(\mathrm{CB}_{2}\right)$ might induce antipsychotic effect (Emmet \& Nice, 2009; Iseger \& Bossong, 2015; Kloft, 2017; Peres et al., 2017; Walkey et al., 2018). New evidence supported antipsychotic effect of CBD; lack of $\mathrm{CB}_{2}$ stimulation might increase the risk of developing schizophrenia (Ishiguro et al., 2010). Moreover, antipsychotic effect of CBD is as potent as amisulpride ${ }^{3}$ with more tolerated side effects (Leweke et al., 2012).

Not only show potential as treatment for schizophrenia, cannabis also shows potential as a treatment for individual with neurodegenerative diseases (Bassavarajappa et al., 2017), e.g., Alzheimer's disease (AD), Amyotrophic Lateral Sclerosis (ALS), Huntington's disease (HD), and Parkinson's disease (PsD) (Fernández-Ruiz et al., 2015; Singh \& Joshi, 2019). Cannabis could induce neuroprotection/neurorepair and anti-inflammatory properties through cannabinoid, thus impair the disease progression and alleviating related symptoms (Fernández-Ruiz et al., 2017; Holgado et al., 2017). The findings suggested $C B^{2}$ agonist and cannabinoid receptor type $1\left(\mathrm{CB}_{1}\right)^{4}$ antagonist to be used as a treatment to neurodegenerative diseases (Bassavarajappa et al., 2017; Cassano et al., 2017).

\footnotetext{
${ }^{2}$ Cannabinoids are chemical compounds found in cannabis There are two main cannabinoids, i.e., delta-9-tetrahydrocannabinol ( $\triangle 9$-THC) and cannabidiol (CBD) (Emmet \& Nice, 2009). The two of them have opposing effects, while $\triangle 9$-THC might induce psychotic-like effects, CBD might induce antipsychotic effects (Iseger \& Bossong, 2015; Walkey et al., 2018).

${ }^{3}$ A potent antipsychotic drug (Leweke et al., 2012).

${ }^{4}$ Along with CB1, endogenously produced cannabinoids (endocannabinoids) that binds to cannabinoid receptor, and catabolic enzymes to cannabinoids, they formed the endocannabinoid system (ECS) (Bassavarajappa et al., 2017).
} 
Based on presented preliminary data, this article aims (1) to explore the effects induced by cannabis in human cognitive functions and (2) to explore which part of the brain correlated with cognitive functions affected by cannabis consumption. Both objectives are important since cannabis is the most consumed but the least researched PS (especially) in Indonesia. Moreover, it is important since $24 \%$ of the previous year prevalence are student (BNN \& UI, 2017)).

\section{Cannabis and Cognitive Functions}

Memorizing, reasoning, thinking, and perception are parts of cognitive functions (Evren, 2017). Poorer cognitive function often associated with chronic and heavy consumption to cannabis (Sagar \& Gruber, 2018). Moreover, cannabis consumption during adolescence often associated with poorer attention, memory, processing, IQ, inhibition, and decision-making ability (Wright et al., 2017).

However, the associations could not be generalized. Many other studies suggested the opposite. One of them came from Indonesia, as Widodo and Surjaningrum (2014) found that there is no significant difference on working memory test ${ }^{5}$ between cannabis consumers and non-consumers ${ }^{6}$.

Population based studies shows that there is no significant difference on the cognitive functions between cannabis consumers and non-consumers (Ross et al., 2020; Scott et al., 2017). Furthermore, occasional consumers ( $\leq 2$ per week; $n=940$ ) tend to perform slightly better than non-consumers on executive control, social cognition, and memory test (Scott et al., 2017). Besides, through quasi-experiment design on twins $(n=856)$ from 438 families, it could be summarized that moderate consumption to cannabis did not lead to poorer cognitive functions (Ross et al., 2020). Population based research in Germany also suggested that consuming cannabis on mild to moderate level did not lead to poorer executive functions (Piechatzek et al., 2009). Not only that, a systematic review and meta-analysis on consuming cannabis during adolescence also suggested that cannabis did not lead to poorer cognitive functions (Scott et al., 2018).

Atypical sampling method used by population-based studies becomes the reason why those studies often found that consumption of cannabis might not lead to poorer cognitive functions. Studies with positive findings that cannabis use leads to poor cognitive function usually employ typical sampling method, i.e., clinical population, which is exposed to bias since most of individuals are looking for help to overcome cannabis-related problems (Scott et al., 2017). Moreover, if there is such thing called poorer cognitive functions due to cannabis consumption, it is only temporary and might be reversed after a period of abstinence (Mizrahi et al., 2017; Scott et al., 2018). Even for chronic consumer, poorer cognitive functions due to cannabis consumption might be reversed after a period of abstinence (Mizrahi et al., 2017). Poor cognitive functions due to cannabis consumption ceases in average of seventy-two hours (Scott et al., 2018).

If poorer cognitive functions proved to be persistent after a period of abstinence, Solowij et al.

${ }_{5}^{5}$ Widodo and Surjaningrum (2014) used central executive, visuo-spatial, phonological loop, and episodic buffer to assess working memory.

${ }^{6}$ The title of the research refers to individual with cannabis-related disorder (pecandu) and non-cannabis-related disorders (bukan pecandu However, the method used in research explain that the groups are divided into social-recreational consumer and non-consumer (Widodo \& Surjaningrum, 2014). 
(2018) suggested a therapy using cannabinoid constituent, i.e., CBD. Two-hundreds milligrams of daily oral CBD for ten weeks proved to be effective to improve cognitive-related conditions and other-related symptoms. The improvement occurred without having a period of abstinence, thus did not interrupt regular pattern of cannabis consumption.

\section{Endocannabinoid System (ECS) and Cannabinoids Effects to Human Brain}

Cannabis known for affecting human cognitive and emotion functions (Zanettini et al., 2011). It is due to the ECS (see annotation number 4) widely spread in various brain regions. Several rationalizations made to examine ECS, since it plays important roles in regulating learning (Marsicano \& Lafenetre, 2009), memory (Bossong, Jager, et al., 2012; Marsicano \& Lafenetre, 2009) and emotion processes (Bossong, Jansma, Hell, Jager, Kahn, et al., 2013).

A meta-analysis on the use of Functional Magnetic Resonance Imaging (fMRI) and/or Positron Emission Tomography (PET) found that cannabis consumption might increase activation on the striatum and decrease activation on the anterior cingulate cortex (ACC) and the dorsolateral prefrontal cortex (DL-PFC). Decreased activation on ACC, DL-PFC and related brain networks provides neurobiological explanation why cannabis consumption might disrupt task performances. Furthermore, increase activation on striatal, followed by activation on prefrontal, parietal, and other limbic areas are associated with reward processing (Yanes et al., 2018).

Animal based research found that ECS plays important roles on rewards processing. Although it is not yet confirmed on human, ECS correlates with rewards appreciation process. Through fMRI, it is discovered that inferior parietal and temporal cortex are the most activated regions during rewards appreciation process on human (G. Hell et al., 2011).

Aside from the endocannabinoids, neurotransmitter often associated with the brain reward systems is dopamine (Wise \& Rompre, 1989). Not only reward systems, dopamine is also an important neurotransmitter to working memory. Increasing this neurotransmitter or assisting its performance means improving working memory, vice versa (Gibbs \& D'Esposito, 2005; Sawaguchi, 2001). It is interesting since activating $\mathrm{CB}_{1}$ receptor might improve ECS performance to balance dopaminergic signaling on various brain regions (Lau \& Schloss, 2008).

Other studies suggested that activating ECS might induce poor working memory performance (Bossong, Jansma, Hell, Jager, Oudman, et al., 2012; Zanettini et al., 2011). It is concluded after administrating $\Delta^{9}$-THC to 25 healthy participants. Moreover, $\Delta^{9}$-THC also affecting the whole working memory system, especially the cerebellum, the left dorsolateral prefrontal cortex, the inferior temporal gyrus, and the inferior parietal gyrus. Poor working memory performance might be due to $\Delta^{9}$-THC-induced lowered general alertness (Bossong, Jansma, Hell, Jager, Oudman, et al., 2012). Au contraire, Marsicano and Lafenetre (2009) suggested that high levels of ECS might not induce poor working memory. In fact, increasing anandamide ${ }^{7}$ levels and facilitating ECS signaling through fatty acid amide hydrolase ${ }^{8}$ (FAAH) inhibitor might improve learning ability ${ }^{9}$ (Zanettini et al., 2011).

\footnotetext{
${ }^{7}$ Is the first discovered neurotransmitter of ECS. Anandamide means internal bliss (Pinel, 2009).

${ }^{8}$ Might induce catabolism to anandamide (Deutsch \& Chin, 1993).

${ }^{9}$ Is one of the mental functions referred by the word cognition besides motivation, planning, memory, and other
} 
Working memory is a part of executive functions besides response inhibition ${ }^{10}$ and cognitive flexibility ${ }^{11}$ (Diamond, 2013). $\Delta^{9}$-THC on $500 \mu \mathrm{g} / \mathrm{kg}$ did not induce poor executive functions. It is concluded using double-blind, placebo controlled, two-way mixed design to 12 occasional and 12 regular cannabis consumers (Ramaekers et al., 2008).

Furthermore, based on systematic review, it could not be determined whether cannabis and/or $\Delta^{9}$-THC might induce poor working memory and cognitive flexibility or not. However, $\Delta^{9}$-THC response inhibition. Neuroimaging results shows that poor respoclearly induces poornse inhibition is modulated by neural process in the inferior frontal gyrus (Oomen et al., 2018).

Studies that aimed to determine effects of $\Delta^{9}$-THC and CBD to response inhibition found that $\Delta^{9}$-THC administration might decrease activation on the right inferior frontal and the anterior cingulate gyrus, whilst CBD to the left temporal and the insula. It is concluded that compared to $\mathrm{CBD}, \Delta^{9}$-THC shows more involvement in response inhibition, since CBD tends to modulate function that does not correlate with response inhibition. Nevertheless, both $\Delta^{9}$-THC and CBD do not disrupt response inhibition performance, although $\Delta^{9}$-THC tends to modulate activities within the brain regions that mediate response inhibition (Borgwardt et al., 2008). Response inhibition performance tends to be disrupted by $\Delta^{9}$-THC administration on individual with psychosis-like effects after administration. Neuroimaging results show that there are certain brain regions activation differences between individual with psychosis-like effects and non-psychosis-like effects. Individual with psychosis-like effects tend to experience activation in the left parahippocampal gyrus, the left and right middle temporal gyrus, and the right cerebellum (Atakan et al., 2012). The cerebellum itself is associated with physical coordination abilities (Smith \& Kosslyn, 2014).

Despite no evidence supporting $\Delta^{9}$-THC induce poor response inhibition performances (Borgwardt et al., 2008), there is evidence of executive function disruption after $\Delta^{9}$-THC administration (Bossong, Hell, et al., 2013) - whether the disruption included psychosis-like effects is unknown (Atakan et al., 2012). During the task performances, the disruption is associated with increasing activity on a set of brain regions linked to default mode network. Naturally, during task performances goal-oriented behavior the default mode network would be deactivated. Increasing activity in the default mode network touted as the main reason for poor executive and cognitive functions (Bossong, Hell, et al., 2013).

Default mode network is an emerging condition when an individual inactively engaged in task. While in this condition, the brain planning an action but does not act them out, creating various scenarios from a single situation. The brain regions are actively involved during this condition is the medial and lateral frontal cortex. Actively, medial frontal cortex indicates social rumination ${ }^{12}$ whilst

analysis aspect of thinking abilities (Mai et al., 2005).

${ }^{10}$ Including response inhibition (self-control; restraining self from desire and impulsive behavior) and interference control (selective inhibition to cognition and attention) (Diamond, 2013). Response inhibition correlates with inhibiting an out-of-context-act or act that would obstruct goal-driven behavior (Mostofsky \& Simmonds, 2008).

11 Including creative thinking, using various perspectives, and adapting in a fast and flexible way to a fast-changing circumstances (Diamond, 2013).

${ }^{12}$ During default mode network, we tend to experience rumination concerning our relationships with others and the position we hold within the social world (Carter et al., 2019). 
lateral frontal cortex indicating sequential thinking patterns suited to handling objects. This condition would take individual to a solution through free-floating nature of thinking (Carter et al., 2019).

Besides the medial and lateral frontal cortex, there is also the parietal region which enabling the creation of various scenario (Carter et al., 2019). Activated parietal region during default mode network enabling individual to recall information from the long-term memory (Sestieri et al., 2011). Thus, making it more interesting considering ECS plays important role in regulating memory processes (Bossong, Jager, et al., 2012; Marsicano \& Lafenetre, 2009).

Implied regulation might be associate with how inhibiting ECS would increase memory ability (Zanettini et al., 2011). Furthermore, based on meta-analysis, the ability to learn and remember new information in chronic cannabis consumer might decrease, although the magnitude of effect is very small (Grant et al., 2003). Long-term habituation might provide an answer to the decreasing ability (Riedel \& Davies, 2005).

According to various studies, acute (high dose and on relatively short time) cannabis consumption might induce decreasing ability of learning and memory than regular and chronic consumption (Riedel \& Davies, 2005). However, if there is such thing as decreasing memory ability, it might be induced by the effects of $\Delta^{9}$-THC to the medial temporal lobe region ${ }^{13}$ (Bhattacharyya et al., 2009). Besides, during the coding administration, $\Delta^{9}$-THC tends to reduce the right insular, the right inferior frontal gyrus, and the left-middle occipital gyrus activity and increasing the bilateral cuneus ${ }^{14}$ and precuneus ${ }^{15}$ activity during the information retrieval (Bossong, Jager, et al., 2012).

$\mathrm{CB}_{1}$ antagonists might play roles in improving memory ability by increasing brain plasticity (Riedel \& Davies, 2005). Brain plasticity is a phenomenon that helps brain recovery due to certain conditions, e.g., stroke and traumatic brain injury (Mateos-Aparicio \& Rodriguez-Moreno, 2019). In addition to improve specific ability such as memory, $\mathrm{CB}_{1}$ antagonists (e.g., $\mathrm{CBD}$ ) might also improve cognitive abilities in general through various mechanisms, i.e., pro-inflammatory cytokines, brain immune cells (e.g., microglia and astrocytes), oxidative stress, inducing neurogenesis, and increasing serotonin and adenosine (Osborne et al., 2017).

Previous research on cognitive functions deficiency confirmed that CBD could be used to improve cognitive functions (Osborne et al., 2017). Moreover, based on pre- and clinical studies, ECS play roles in cognitive deficiency pathophysiology due to psychological disorders (H. Hell et al., 2011). Ringen et al. (2009) found that consuming cannabis is associated with increasing executive functions on 133 individuals with bipolar disorder. Increasing executive functions was based on assessment and comparison of neurocognitive abilities between cannabis and non-cannabis consumers with bipolar disorder.

Increased executive functions were also found on 11 medical cannabis consumers. All the 11 individuals consumed medical cannabis after 10 years period of abstinence or never have been consuming before. The 11 individuals consumed cannabis as a medication to anxiety, depressive, sleep

\footnotetext{
${ }_{13}^{13}$ Includes hippocampus, perirhinal, ethorhinal, and parahippocampal (Squire et al., 2004).

${ }^{14}$ Bilateral cuneus is cuneus and precuneus. Cuneus is located within occipital (Bossong, Jager, et al., 2012).

${ }^{15}$ Located between the brain hemispheres. Along with posterior cingulate cortex (PCC), it might play roles in memory formation, especially when it comes to self (Carter et al., 2019).
} 
disorder, chronic pain, and other disorders (Gruber et al., 2016)). Furthermore, medical cannabis was also found to improve activation patterns in the cingulate cortex and the frontal regions-suggesting normalization of brain function relative to control group. It is observed using fMRI after three months of medical cannabis consumption. The participants had never consumed cannabis or had through two years period of abstinence. Besides activation patterns, the participants also showed better performance on Multi-Source Interference Task (MSIT) ${ }^{16}$ compared to pre-test (Gruber et al., 2018).

\section{Conclusions}

It could not be determined whether cannabis induce positive or negative effects to human cognitive functions. It is based on various sources we found and used in this article. One of the factors affecting our conclusions is sampling technique used by each study. Studies that sampled individuals with cannabis-related disorders tend to find poor cognitive functions. However, research that sampling on general population (non-clinical or non-correctional facilities) tend not to find poor cognitive functions.

There are several rationalizations we develop to answer why sampling technique affects the research results. (1) According to BNN and UI (2017), from 1.7\% (3.3 million) of total Indonesian population aged 10-59 years who consume at least one illicit PS within the last year, there are $14.49 \%$ (489.197 individuals) that could be categorized in having non-injecting substance-use disorder and $1.73 \%$ (58,498 individuals) that could be categorized in having injecting substance-use disorder ${ }^{17}$. The number is uneven, thus the study using individuals with cannabis-consumption disorders should not be generalized to the whole population of cannabis consumer.

The next rationalization is (2) related to the health and mental condition of individuals with cannabis-consumption disorder. The studies sampling on individuals with cannabis-consumption disorder typically using individuals who were seeking professional help for the condition they have (Scott et al., 2017). Since they were seeking for professional help, they should have realized that there are certain conditions within self that not functioning well, have they not? And it is possible that the conditions itself are linked with their cognitive functions. Besides, we should (3) consider whether it is a single consumption to cannabis or poly-PS (poly-drugs) consumption (Riedel \& Davies, 2005) while determining the association between consumption and poor cognitive functions.

In addition to the history of PS that ever or being consumed, the consideration must involve (4) the level of consumption. It is due to the research (Piechatzek et al., 2009; Ross et al., 2020) that found mild to moderate consumption did not induce significant affect to cognitive functions. Conversely, chronic and heavy consumption might induce poor cognitive functions. Furthermore, we should consider the opportunities of the consumers have in sharpening cognitive functions (Widodo

\footnotetext{
${ }^{16}$ Could be used to identify the cognitive networks or attention and to assess integration of the networks (Bush \& Shin, 2006).

17 The exact words used by BNN and UI (2017) are injecting addiction (pecandu suntik) and non-injecting addiction (pecandu bukan suntik). It is based on route of consumption, using injection and non-injection, and the frequency of consumption within the last year
} 
\& Surjaningrum, 2014), attention, and goal-based learning (Riedel \& Davies, 2005).

Apart from the sampling technique, another factor affecting our conclusions is arose from the cannabis itself. Opposite nature of cannabinoids constituent, i.e., $\Delta^{9}-\mathrm{THC}$ and CBD might induce psychotic-like and antipsychotic effects to its consumer. Psychotic-like effects often associated with poor cognitive functions, whilst antipsychotic effects alleviated poor cognitive functions. Yet, we have not considered how both of them works when consumed as cannabis joint which contains cannabinoids as a whole compound.

Cannabis is also found to affect various brain regions facilitating cognitive functions. It is discovered after administrating $\Delta^{9}$-THC or CBD and then assessing its effect using fMRI. The assumptions used to administrate is to activate ECS within the brain. Neuroimaging results of the fMRI shows that ECS play roles in brain regions correlates with executive functions (Ramaekers et al., 2008), consist of working memory (Bossong, Jansma, Hell, Jager, Oudman, et al., 2012; Marsicano \& Lafenetre, 2009; Zanettini et al., 2011), response inhibition (Atakan et al., 2012; Borgwardt et al., 2008; Bossong, Hell, et al., 2013; Oomen et al., 2018), and cognitive flexibility (Ramaekers et al., 2008). Moreover, ECS also play roles in other brain regions associated with memory-memory ability (Bhattacharyya et al., 2009; Bossong, Jager, et al., 2012; Grant et al., 2003; Marsicano \& Lafenetre, 2009; Riedel \& Davies, 2005; Zanettini et al., 2011).

Poor cognitive functions due to consuming cannabis-or certain cannabinoid-might be induced by increasing activity of the default mode network during task performances-goal-oriented behavior - the default mode network would be deactivated. Increasing activity in the default mode network touted as the main reason for poor executive and cognitive functions (Bossong, Hell, et al., 2013). Moreover, poor cognitive performances after consuming cannabis might be due to ineffective neural processing, including activated brain regions atypically associated with cognitive performances (Sagar \& Gruber, 2018). However, cannabis or cannabinoid consumption might improve cognitive functions on individuals with bipolar (Ringen et al., 2009), anxiety, depressive, sleep disorder, chronic pain (Gruber et al., 2016), and might be other disorders as well (Gruber et al., 2016; G. Hell et al., 2011; Osborne et al., 2017).

There is evidence suggesting consuming cannabis during adolescence did not induce poor cognitive functions (Scott et al., 2018). Riedel and Davies (2005) suggested that if there are such thing as poor cognitive functions due to cannabis consumption, it is more because of lack of attention and goal-based learning. Furthermore, education might also affect the cognitive functions of cannabis consumers (Widodo \& Surjaningrum, 2014). Widodo and Surjaningrum (2014) argued that the insignificant difference between control and treatment group on working memory test is due to the same education background between the groups. The findings shows that although consuming cannabis, the treatment group still had an opportunity to sharpen their cognitive functions. It also provides preliminary evidence that by sharpening the cognitive functions, cannabis consumer might alleviate risk factor of developing poor cognitive functions, especially within the context of Indonesia.

Future research on the cognitive functions of cannabis consumer should really taking population in which they tried to sample into consideration. It is important especially when it comes to make a 
generalization. The research that sampling on clinical or correctional facility population should not generalize their results to general population of cannabis consumer that may contain recreational or abstinence consumer. Moreover, it is delicate to determine causality relationship between consuming cannabis and poor cognitive functions. Ideally, an experiment of administrating cannabis within certain amount of time to healthy and identical participants on the term of cognitive functions would do the trick, yet unethical. Therefore, future research emphasized on correlational relationship between consuming cannabis within certain population and cognitive functions should take typical social-demographic factors into consideration.

\section{Declarations}

Acknowledgement

There is no acknowledgement made by the authors.

Funding

Authors did not receive any funding during conceptualizing, writing, and reporting this article.

Conflict of Interest

All authors have no conflict of interest in reporting this article.

Author's Contribution

Conceptualization and writing provided by Wurgan Rahadian and Abraham Sabda Respati, whilst review and supervision provided by Supra Wimbarti and Sri Kusrohmaniah.

ORCID ID

Wurgan Rahadian https:/ / orcid.org/0000-0002-4338-8979

Abraham Sabda Respati https:/ / orcid.org/0000-0001-8993-9812

Supra Wimbarti https:/ / orcid.org/0000-0003-2821-2403

Supra Kusrohmaniah https:/ / orcid.org/0000-0002-1767-7718

\section{References}

Andréasson, S., Engström, A., Allebeck, P., \& Rydberg, U. (1987). Cannabis and schizophrenia: A longitudinal study of swedish conscripts. The Lancet, 330(8574), 1483-1486. https: / / doi.org/ 10.1016/s0140-6736(87)92620-1

Arseneault, L., Cannon, M., Poulton, R., Murray, R., Caspi, A., \& Moffitt, T. (2002). Cannabis use in adolescence and risk for adult psychosis: Longitudinal prospective study. British Medical Journal, 325(7374), 1212-1213. https:/ / doi.org/10.1136/bmj.325.7374.1212 
Atakan, Z., Bhattacharyya, S., Allen, P., Martín-Santos, R., Crippa, J., Borgwardt, S., \& McGuire, P. (2012). Cannabis affects people differently: Inter-subject variation in the psychotogenic effects of 89 -tetrahydrocannabinol: A functional magnetic resonance imaging study with healthy volunteers. Psychological Medicine, 43(6), 1255-1267. https : / / doi . org / 10.1017 / s0033291712001924

Balhara, Y., \& Jain, R. (2014). Cannabis use among opioid-dependent individuals on opioid substitution therapy. Journal of Pharmacology and Pharmacotherapeutics, 5(3), 203-205. https: / / doi.org/10. 4103/0976-500x.136106

Bassavarajappa, B., Shivakumar, M., Joshi, V., \& Subbanna, S. (2017). Endocannabinoid system in neurodegenerative disorders. Journal of Neurochemistry, 142(5), 624-648. https: / / doi.org/10. 1111/jnc.14098

Bhattacharyya, S., Fusar-Poli, P., Borgwardt, S., Martin-Santos, R., Nosarti, C., O'Carroll, C., \& McGuire, P. (2009). Modulation of mediotemporal and ventrostriatal function in humans by 89 -tetrahydrocannabinol: A neural basis for the effects of cannabis sativa on learning and psychosis. Archives of General Psyciatry, 66(4), 442-451. https: / / doi . org / 10.1001 / archgenpsychiatry.2009.17

Blakemore, S.-J. (2008). The social brain in adolescence. Nature Reviews Neuroscience, 9(4), 267-277. https: //doi.org/10.1038/nrn2353

Blakemore, S.-J., \& Choudhury, S. (2006). Development of the adolescent brain: Implications for executive function and social cognition. Journal of Child Psychology and Psychiatry, 47(3-4), 296-312. https://doi.org/10.1111/j.1469-7610.2006.01611.x

BNN, \& UI. (2017). Survey nasional penyalahgunaan narkoba di 34 provinsi tahun 2017[national survey of drug abuse in 34 provinces in 2017]. Jakarta, Indonesia, Pusat Penelitian Data dan Informasi Badan Narkotika Nasional Republik Indonesia [BNN] \& Pusat Penelitian Kesehatan Universitas Indonesia [UI].

Borgwardt, S., Allen, P., Bhattacharyya, S., Fusar-Poli, P., Crippa, J., Seal, M., \& McGuire, P. (2008). Neural basis of $\delta$-9-tetrahydrocannabinol and cannabidiol: Effects during response inhibition. Biological Psychiatry, 64(11), 966-973. https://doi.org/10.1016/j.biopsych.2008.05.011

Bossong, M., Hell, H., Jager, G., Kahn, R., Ramsey, N., \& Jasma, M. (2013). The endocannabinoid system and emotional processing: A pharmacological fmri study with 89 -tetrahydrocannabinol. European Neuropsychopharmacology, 23(12), 1687-1697. https:/ / doi.org/10.1016/j.euroneuro. 2013.06.009

Bossong, M., Jager, G., Hell, H., Zuurman, L., Jansma, J., Mehta, M., \& Ramsey, N. (2012). Effects of 69-tetrahydrocannabinol administration on human encoding and recall memory function: A pharmacological fmri study. Journal of Cognitive Neuroscience, 24(3), 588-599. https:/ / doi.org/ 10.1162/jocn_a_00156

Bossong, M., Jansma, J., Hell, H., Jager, G., Kahn, R., \& Ramsey, N. (2013). Default mode network in the effects of 89 -tetrahydrocannabinol (thc) on human executive function. PloS ONE, 8(7), e70074. https://doi.org/10.1371/journal.pone.0070074 
Bossong, M., Jansma, J., Hell, H., Jager, G., Oudman, E., Saliasi, E., \& Ramsey, N. (2012). Effects of 89 -tetrahydrocannabinol on human working memory function. Biological Psychiatry, 71(8), 693-699. https:/ /doi.org/10.1016/j.biopsych.2012.01.008

Bush, G., \& Shin, L. (2006). The multi-source interference task: An fmri task that reliably activates the cingulo-frontal-parietal cognitive/attention network. Nature Protocols, 1(1), 308-313. 10.1038/ nprot.2006.48

Carter, R., Aldridge, S., Page, M., \& Parker, S. (2019). The human brain book (3rd). DK Publishing.

Cassano, T., Calcagnini, S., Pace, L., De Marco, F., Romano, A., \& Gaetani, S. (2017). Cannabinoid receptor 2 signalling in neurodegenerative disorders: From pathogenesis to a promising therapeutic target. Frontiers in Neuroscience, 11, 30. https:/ / doi.org/10.3389/fnins.2017.00030

Deutsch, D., \& Chin, S. (1993). Enzymatic synthesis and degradation of anandamide, a cannabinoid receptor agonist. Biochemical Pharmacology, 46(5), 791-796. https: / / doi.org / 10.1016 / 0006 2952(93)90486-g

Diamond, A. (2013). Executive functions. Annual Review of Psychology, 64, 135-168. https:/ /doi.org/10. 1146/annurev-psych-113011-143750

Emmet, D., \& Nice, G. (2009). What you need to know about cannabis: Understanding the facts. London, UK, Jessica Kingsley Publishers.

Evren, C. (2017). Cannabis use and cognitive function. In V. Preedy (Ed.), Handbook of cannabis and related pathologies: Biology, pharmacology, diagnosis, and treatment (pp. 70-78). London, UK, Academic Press.

Fernández-Ruiz, J., Gómez-Ruiz, M., García, G., Hernández, M., \& Ramos, J. (2017). Modelling neurodegenerative disorders for developing cannabinoid-based neuroprotective therapies. Methods in Enzymology, 593, 175-198. https://doi.org/10.1016/bs.mie.2017.06.021

Fernández-Ruiz, J., Romero, J., \& Ramos, J. (2015). Endocannabinoids and neurodegenerative disorders: Parkinson's disease, huntington's chorea, alzheimer's disease, and others (R. Pertwee \& Endocannabinoids, Eds.). Cham, Switzerland, Springer International Publishing Switzerland.

Gibbs, S., \& D’Esposito, M. (2005). Individual capacity differences predict working memory performance and prefrontal activity following dopamine receptor stimulation. Cognitive, Affective, \& Behavioral Neuroscience, 5(2), 212-221. https://doi.org/10.3758/cabn.5.2.212

Grant, I., Gonzalez, R., Carey, C., Natarajan, L., \& Wolfson, T. (2003). Non-acute (residual) neurocognitive effects of cannabis use: A meta-analytic study. Journal of the International Neuropsychological Society, 9(5), 679-689.

Gruber, S., Sagar, K., Dahlgren, M., Gonenc, A., Smith, R., Lambros, A., \& Lukas, S. (2018). The grass might be greener: Medical marijuana patients eexhibit altered brain activity and improved executive function after 3 months of treatment. Frontiers in Pharmacology, 8, 983.

Gruber, S., Sagar, K., Dahlgren, M., Racine, M., Smith, R., \& Lukas, S. (2016). Splendor in the grass? a pilot study assessing the impact of medical marijuana on executive function. Frontiers in Pharmacology, 7, 355. 
Hell, G., H.H. d Jager, Bossong, M., Brouwer, A., Jansma, J., Zuurman, L., \& Ramsey, N. (2011). Involvement of the endocannabinoid system in reward processing in the human brain. Psychopharmacology, 219(4), 981-990. https://doi.org/10.1007/s00213-011-2428-8

Hell, H., Bossong, M., Jager, G., Kahn, R., \& Ramsey, N. (2011). Methods of pharmacological imaging of the cannabinoid system (phics) study: Towards understanding the role of the brain endocannabinoid system in human cogntion. International Journal of Methods in Psychiatric Research, 20(1), 10-27. https://doi.org/10.1002/mpr.327

Holgado, M., Martín-Banderas, L., Álvarez-Fuentes, J., \& Fernández-Arévalo, M. (2017). Neuroprotective effect of cannabinoids nanoplatforms in neurodegenerative diseases. Journal of Drug Delivery Science and Technology, 42, 84-93.

Iseger, T., \& Bossong, M. (2015). A systematic review of the antipsychotic properties of cannabidiol in humans. Schizophrenia Research, 162(1-3), 153-161.

Ishiguro, H., Horiuchi, Y., Ishikawa, M., Koga, M., Imai, K., Suzuki, Y., \& Arinami, T. (2010). Brain cannabinoid cb2 receptor in schizophrenia. Biological Psychiatry, 67(10), 974-982.

Kloft, L. (2017). The efficacy of cannabidiol (cbd) as potential antipsychotic medication. Maastricht student journal of psychology and neuroscience, 6(1), 1-15.

Konrad, K., Firk, C., \& Uhlhaas, P. (2013). Brain development during adolescence: Neuroscientific insights into this development period. Deutsches Ärzteblatt International, 110(25), 425-431.

Lau, T., \& Schloss, P. (2008). The cannabinoid cb1 receptor is expressed on serotonergic and dopaminergic neurons. European Journal of Pharmacology, 578(2-3), 137-141.

Leweke, F., Piomelli, D., Pahlisch, F., Muhl, D., Gerth, C., Hoyer, C., \& Koethe, D. (2012). Cannabidiol enhances anadamide signaling and alleviates symptoms of schizophrenia. Translational Psychiatry, 2(3), 94.

Mai, L., Owl, M., \& Kersting, M. (2005). The cambridge dictionary of human biology and evolution. Cambridge, UK, Cambridge University Press.

Marsicano, G., \& Lafenetre, P. (2009). Roles of the endocannabinoid system in learning and memory. In Behavioral neurobiology of the endocannabinoid system (pp. 201-230). Springer Berlin Heidelberg. https:/ / doi.org/10.1007/978-3-540-88955-7_8

Mateos-Aparicio, P., \& Rodriguez-Moreno, A. (2019). The impact of studying brain plasticity. Frontiers in Cellular Neuroscience, 13, 66. https://doi.org/10.3389/fncel.2019.00066

Mizrahi, R., Watts, J., \& Tseng, K. (2017). Mechanisms contributing to cognitive deficits in cannabis users. Neuropharmacology, 124, 84-88.

Mostofsky, S., \& Simmonds, D. (2008). Response inhibition and response selection: Two sides of the same coin. Journal of Cognitive Neuroscience, 20(5), 751-761.

Nusantara, L. G. (2014). Sekarang aku, besok kamu!: Panduan hukum bagi warga negara pengguna ganja[today $i$, tomorrow you!: A legal guide for cannabis-using citizens] (1st ed.). Lingkar Ganja Nusantara.

Oomen, P., Hell, H., \& Bossong, M. (2018). The acute effects of cannabis on human executive function. Behavioural Pharmacology, 29(7), 606-616. 


\section{Rahadian et al || Cognitive Deficiency}

Osborne, A., Solowij, N., \& Weston-Green, K. (2017). A systematic review of the effect of cannabidiol on cognitive function: Relevance to schizophrenia. Neuroscience $\mathcal{E}$ Biobehavioral Reviews, 72, 310-324.

Peres, F., Almeida, V., \& Abilio, V. (2017). Cannabidiol: An overview of its antipsychotic properties. In V. Preedy (Ed.), Handbook of cannabis and related pathologies (pp. 787-794). London, UK, Academic Press.

Piechatzek, M., Indlekofer, F., Daamen, M., Blasmacher, C., Lieb, R., Pfister, H., \& Schütz, C. (2009). Is moderate substance use associated with altered executive functioning in a population-based sample of young adults. Human Psychopharmacology Clinical and Experimental, 24, 650-665. https://doi.org/10.1002/hup.1069

Pinel, J. (2009). Biopsikologi (7thed.). (h. p. soetjipto, \& s. m. soetjipto, trans.) Yogyakarta, Indonesia, Pustaka Pelajar.

Ramaekers, J., Kauert, G., Theunissen, E., Toennes, S., \& Moeller, M. (2008). Neurocognitive performance during acute (thc) intoxication in heavy and occasional cannabis users. Journal of Psychopharmacology, 23(3), 266-277. https://doi.org/10.1177/0269881108092393

Riedel, G., \& Davies, S. (2005). Cannabinoid function in learning, memory and plasticity. In R. Pertwee (Ed.), Cannabinoids (pp. 445-477). Belin, Germany, Springer-Verlag.

Ringen, P., Vaskinn, A., Sundet, K., Engh, J., Jónsdóttir, H., Simonsen, C., \& Andreassen, O. (2009). Opposite relationships between cannabis use and neurocognitive functioning in bipolar disorder and schizophrenia. Psychological Medicine, 40(8), 1337-1347. https: / / doi . org / 10. $1017 /$ s0033291709991620

Ross, J., Ellingson, J., Rhee, S., Hewitt, J., Corley, R., Lessem, J., \& Friedman, N. (2020). Investigating the causal effect of cannabis use on cognitive function with a quasi-experimental co-twin design. Drug and Alcohol Dependence, 206, 107712. https:/ / doi.org/10.1016/j.drugalcdep.2019.107712

Sagar, K., \& Gruber, S. (2018). Interactions between recreational cannabis use and cognitive function: Lesson from functional magentic resonance imaging. Annals of the New York Academy of Sciences, 1451(1), 42. https:/ / doi.org/10.1111/nyas.13990

Saputro, W. (2018). Implementasi kebijakan pendayagunaan tanaman ganja di indonesia melalui uu narkotika no. 35 tahun 2009[implementation of policies on the utilization of cannabis plants in indonesia through the narcotics law no. 35 year 2009. Universitas Brawijaya. http:/ / repository.ub.ac.id/163267/

Sawaguchi, T. (2001). The effects of dopamine and its antagonists on directional delay-period activity of prefrontal neurons in monkeys during an oculomotor delayed-response task. Neuroscience Research, 41(2), 115-128. https:/ / doi.org/10.1016/s0168-0102(01)00270-x

Scott, J., Slomiak, S., Jones, J., Rosen, A., Moore, T., \& Gur, R. (2018). Association of cannabis with cognitive functioning in adolecent and young adults: A systemic review and meta-analysis. JAMA Psychiatry, 75(6), 585-595. https://doi.org/10.1001/jamapsychiatry.2018.0335

Scott, J., Wolf, D., Calkins, M., Bach, E., Weidner, J., Kosha, R., \& Gur, R. (2017). Cognitive functioning of adolescent and young adult cannabis users in philadelphia neurodevelopmental cohort. Psychology of Addictive Behaviors, 31(4), 423-434. https://doi.org/10.1037/adb0000268 
Sestieri, C., Corbetta, M., Romani, G., \& Shulman, G. (2011). Episodic memory retrieval, parietal cortex, and the default mode network: Functional and topographic analyses. Journal of Neuroscience, 31(12), 4407-4420. https:/ / doi.org/10.1523/JNEUROSCI.3335-10.2011.

Singh, S., \& Joshi, N. (2019). Preface. In S. Singh, N. Joshi, \& Pathology (Eds.), Prevention and therapeutics of neurodegenerative disease. Singapore, Singapore.

Smith, E., \& Kosslyn, S. (2014). Psikologi kognitif: Pikiran dan otak[cognitive psychology: Mind and brain] (H. Prajitno \& S. Soetjipto, Eds.). Yogyakarta, Indonesia, Pustaka Pelajar.

Solowij, N., Broyd, S. J., Beale, C., Prick, J.-A., Greenwood, L.-m., van Hell, H., Suo, C., Galettis, P., Pai, N., Fu, S., Croft, R. J., Martin, J. H., \& Yucel, M. (2018). Therapeutic effects of prolonged cannabidiol treatment on psychological symptoms and cognitive function in regular cannabis users: A pragmatic open-label clinical trial. Cannabis and Cannabinoid Research, 3(1), 21-34. https://doi.org/10.1089/can.2017.0043

Squire, L., Stark, C., \& Clark, C. (2004). The medial temporal lobe. Annual Review of Neuroscience, 27(1), 279-306. https://doi.org/10.1146/annurev.neuro.27.070203.144130

Sujono, A., \& Daniel, B. (2013). Komentar dan pembahasan undang-undang nomor 35 tahun 2009 tentang narkotika[comments and discussion of law number 35 of 2009 on narcotics]. Sinar Grafika.

Undang-undang Nomor 35 Tahun 2009 tentang Narkotika. (2009). Undang-undang no 35 tahun 2009 tentang narkotika[law number 35 of 2009 concerning narcotics].

Walkey, L., Tanguay, R., \& el-Guebaly, N. (2018). Narrative review of cannabidiol as an antipsychotic and recommendations for legal regulations. The Canadian Journal of Addiction, 9(3), 23-29.

Widodo, W., \& Surjaningrum, E. (2014). Studi perbandingan kemampuan working memory pada pecandu ganja dan non-pecandu ganja[comparative study of working memory ability in marijuana addicts and non-marijuana addicts]. Jurnal Psikologi Klinis dan Kesehatan Mental, 3(2), 72-78. http:/ /journal.unair.ac.id/download-fullpapers-jpkk1f31bdb3dcfull.pdf

Wise, R., \& Rompre, P. (1989). Brain dopamine and reward. Annual Review of Psychology, 40(1), 191-225. https://doi.org/10.1146/annurev.ps.40.020189.001203

Wright, N., Maple, K., \& Lisdahl, K. (2017). Effects of cannabis use on neurocognition in adolescents and emerging adults. In V. Preedy (Ed.), Handbook of cannabis and related pathologies: Biology, pharmacology, diagnosis, and treatment (pp. 151-159). London, UK, Academic Press. https:/ / doi. org/10.1016/b978-0-12-800756-3.00017-x

Yanes, J., Riedel, M., Ray, K., Kirkland, A., Bird, R., Boeving, E., \& Sutherland, M. (2018). Neuroimaging meta-analysis of cannabis use studies reveals convergent functional alterations in brain regions supporting cognitive control and reward processing. Journal of Pharmacology, 32(3), 283-295. https://doi.org/10.1177/0269881117744995

Zanettini, C., Panlilio, L., Aliczki, M., Goldberg, S., Haller, J., \& Yasar, S. (2011). Effects of endocannabinoid system modulation on cognitive and emotional behavior. Frontiers in Behavioral Neuroscience, 5, 57. https://doi.org/10.3389/fnbeh.2011.00057 